\title{
IMPLEMENTATION OF POST REHABILITATION GUIDANCE TO CLIENTS OF CORRECTIONAL INSTITUTION IN THE FRAMEWORK OF PREVENTION OF RELAPSING TO NARCOTICS CRIMINAL ACTS
}

\author{
Djauhari, Aditya Sarjana Putra \\ Lecturer at Faculty of Law, UNISSULA \\ Djauhari00@gmail.com
}

\begin{abstract}
The increased of criminal narcotics is along with economic growth in Indonesia. Narcotics criminal mode includes black drug trafficking, illegal narcotics transactions and misuse. The impact of drug consumption pervades $78 \%$ of deaths between the ages of 19-21 years. Government policy is set to overcome the danger of narcotics through the guidance of correctional clients aiming, restoring the client to become a whole and productive people in the life of society. This research used empirical juridical approach through purposive sampling data collection method by interviewing the free competent guided respondents to answer the researcher's question on the topic of prevention system of Narcotics crime in Penitentiary. The results obtained from this study indicate that the prevention system of narcotic drug crime contains four stages of therapeutic intervention for prison clients namely initial registration, rehabilitation, post-rehabilitation and termination. System output is correctional clients recover from narcotics dependence. The implementation of post-rehabilitation mentoring prioritizes the governance in procedural aspects of administration, fulfillment of facilities, planning, organizing, implementing, monitoring and evaluating. Constraints implementation of post-rehabilitation mentoring includes 2 factors, namely internal and external factors of penitentiary clients. The prevention system improvement solution is the strengthening of client portfolio data upon reassessment in Penitentiary. In addition, budget politics are required in the inflation-friendly provision.
\end{abstract}

\section{Keywords: Post-rehabilitation mentoring, narcotics crime, client of penitentiary}

\section{A. INTRODUCTION}

The increase of crime in Indonesia is along with the economic condition of this nation that has not made society living prosperous. In other words, many Indonesians are under the poverty line. In March 2016, the number of poor people (population with monthly per capita expenditure below the Poverty Line in Indonesia reached 28.01 million people $(10.86 \%)^{1}$. This fact has grown in various ways to meet the needs of life. Narcotics criminal acts, such as the illicit trafficking of narcotics, illegal narcotics transactions, and misuse.

Drug abuse-according to BNN data-3.8 million to 4.2 million Indonesians are struggling with the forbidden goods. Certainly, this amount is not

\footnotetext{
Central Bureau of Statistics. Monday, 18 July 2016. Presentase Penduduk Miskin Maret 2016 Mencapai 10,86\%. https://www.bps.go.id/brs/view/id/1229. Accessed at Wed, 12 April 2016 on 13.10 WIB.
}

a small number. If we deepen the phenomenon of drug abuse, there will be $26 \%$ people try to use, $27 \%$ regular use, $40 \%$ non-injection addicts and $7 \%$ of injecting addicts throughout Indonesia. ${ }^{2}$

The above description illustrates that there are about $50 \%$ of drug abusers need sustainable care. First way is through rehabilitation and second is post-rehabilitation care. Both types of treatments aim to prevent abusers from relapsing. This fact is increasingly alarming when we read that approximately 15 thousand people die each year due to consuming drugs. Ironically, $78 \%$ of the deaths are young people aged between 19-21 years.

The description of the above data shows how much harm the circulation and the use of drugs in this country. Drug threats are not

\footnotetext{
2 National Narcotics Agency Republic of Indonesia, Petunjuk Teknis Layanan Pascarehabilitasi di Bapas, Jakarta, May 2015, p.2.
} 
only worrisome in terms of its disadvantages but also the impact on the productivity of this nation. It is certainly also needs to be noticed.

The young generation who become the backbone of the nation's productivity must be dying because of the use of drugs. Age productive work is around 19-55 years, they face with a reduction in the number of productive populations because of the dangers of drugs. This phenomenon is naturally a burden of the state to cope with it.

The prevalence survey of narcotics abuse in household groups in 20 provinces in 2015 indicated that the prevalence of $1,7 \%$ were drug users. This indicates the spread of narcotics has expanded to various regions in Indonesia. ${ }^{3}$ This condition is a very worrying problem, especially for the Indonesia's young generation. The threat of drug trafficking is transnational. This means a sophisticated organization with traffic between nations. In turn, drugs become viral problems of the world's population. As a step to anticipate the situation and condition of drug prevalence among Indonesian population, the government passed legislation in order to prevent and combat narcotic crime that is Law no. 35 Year 2009 on Narcotics.

The law products produced by the government are not just Law no. 35 of 2009 on Narcotics alone in the case of drug dangers. Another law and regulation are Law no. 12 of 1995 on Corrections. The integrative approach in the handling of narcotics crime is guaranteed in the rights of narcotic prisoners, namely how correctional clients get guidance after rehabilitation.

Statute of the Law no. 12 Year 1995 concerning Penitentiary states that penalization client guidance is fostering clients outside the institution which is one of the penal system against the client. The goal is to form a client to become a whole person, to improve and not to repeat the crime, so that it can be accepted back in the community. They play an active role in development and live a reasonable life as a good and responsible citizen.

3 Research Center for Data and Information National Narcotics Agency of the Republic of Indonesia, 2015, Survei Prevalensi Penyalahgunaan Narkoba pada Kelompok Rumah Tangga di 20 Provinsi Year2015. East Jakarta, p.10.
Law no. 12 of 1995 on Penitentiary regulates more detail about Penitentiary system that is an order about direction and boundary and way of guidance of Penitentiary Prisoners based on Pancasila. It is implemented in an integrated manner between the builder who is nurtured and the society to improve the quality of the Correctional Prisoners to realize their mistake, improve self and does not repeat the crime so that they can be accepted back by the community environment. Furthermore, they can actively play a role in development and can live properly as a good and responsible citizen. ${ }^{4}$ This confirms that the guidance of prisoners, especially narcotics prisoners, becomes the state's obligation, represented by an institution, the Correctional Institution (BAPAS).

The number of narcotics clients handled by the Class I Correctional Center of Semarang as of January 2017 reached 202 clients consisting of 182 men and 20 women clients. This fact shows that the narcotics case in the Class I Correctional Center of Semarang has penetrated into all gender. From the reality of other data there is an opportunity for narcotic prisoners to repeat the crime of narcotics. How does the prevention system of narcotic drug crime applied by Class I Correctional Center of Semarang against correctional clients who get guidance after rehabilitation. How is the implementation of post-rehabilitation guidance to correctional clients in Class I Correctional Center of Semarang. What are the constraints and solutions to improve the implementation of post-rehabilitation guidance to correctional clients in Class I Correctional Center of Semarang.

\section{B. Discussion}

1. The prevention system of narcotic criminal acts applied by the Class I Correctional Center of Semarang against penal clients who get post-rehabilitation guidance

National development is a series of sustainable development efforts covering all aspects of community life, nation and state, to carry out the task of realizing national goals as formulated in the Preamble of the Constitution of the Republic of

4 Directorate General of Correctional Institution, 2016, Standar Bimbingan Klien Dewasa, Jakarta.p.6. 
Indonesia Year 1945. The series of development efforts contain ongoing development activities by raising the level of people's welfare from generation to generation. The implementation of such efforts is done in the context of meeting the needs of the present without compromising the ability of future generations to meet their needs. ${ }^{5}$

Such policies and strategies were done through some community goals. In the realm of demand reduction efforts by the government is a preventive action (prevention) against people who have not been exposed to the dangers of drugs. In addition, for addicts, abusers and victims of narcotics abuse done rehabilitation efforts. Prevention against the dangers of drugs to the community through several actions such as massive campaigns to raise awareness and togetherness of the community refuse and combat the existence of drugs in the community.

Joint Regulation of the Chairman of the Supreme Court of the Republic of Indonesia, Minister of Justice and Human Rights Republic of Indonesia, Minister of Health Republic of Indonesia, Minister of Social Affairs Republic of Indonesia, General Attorney of the Republic of Indonesia and Head of National Police Head of the National Narcotics Board Republic Indonesia Number: 01 / PB / MA / III / 2014 : No. 2014 No. 2014 No. PER-01 / III / 2014 / BNN Regarding the Handling of Narcotics Addicts and Narcotics Abuse Victims Number: Year 2014 Number: PER / 00 / Into the Rehabilitation Institute mandates law enforcement for addicts and narcotics abuse as follows:

1. Pursuant to the provisions of Article 54 of Law no. 35 of 2009 on Narcotics, Narcotics addicts and victims of Narcotics Abuses shall undergo medical rehabilitation and social rehabilitation, and Judges in deciding cases of Narcotics Abuses shall pay attention to the provisions of Article 127 Paragraph (2) and Paragraph (3). ${ }^{6}$

2. As a suspect and/or a defendant undergoing an investigation process, prosecution and trial in court may be given treatment, care and remedy to a

\footnotetext{
5 General Explanation of UU No. 17 year 2007.

6 Chapter 54 Law No. 35 Year 2009 on narcotics
}

medical rehabilitation institution and/or social rehabilitation institution.

While the Government Regulation of the Republic of Indonesia no. 25 Year 2011 Concerning the Implementation of Obligation of Narcotics Addict confirms that the Obligatory Reporting Narcotics Reporting arrangement aims to: ${ }^{7}$

1. Meet the right of drug addicts in obtaining treatment and/or treatment through medical rehabilitation and social rehabilitation.

2. Involve parents, guardians, families and communities in increasing responsibility for drug addicts under their supervision and guidance.

3. Provide information materials for the government in establishing policies in the field of prevention and eradication of abuse and illicit trafficking of narcotics.

The prevention system of narcotic drug reprisals for correctional clients is a set of integrated system components including initial registration, rehabilitation, post-rehabilitation and termination. In the management of addicts, the abuse of narcotic drug abuse is known as continuous rehabilitation. Inside there is a multidisciplinary profession both medical and legal, which mutually reinforce and fill the system so that suspected narcotic criminal acts capable of intervention therapy gradually and sustainably, through coaching in prisons and supervision in Class I Correctional Center of Semarang. Specifically on biopsychosocial, spiritual and vocational interventions. The guidance is done in Class I Correctional Center of Semarang known as post-rehabilitation guidance services. Thus, for penitentiary clients who recover from narcotic dependence can be productive again live in the community, without any demand against drugs.

In the context of preventing the repetition of narcotic crime, post-rehabilitation guidance services cannot be separated from sustainable rehabilitation systems. This domain is juridical played by Correctional Institution. As the researcher has written the sustainable rehabilitation system above, the post-rehabilitation service for addicts, abuse and/or drug abuse victims in Correctional

\footnotetext{
Government Regulation of the Republic of Indonesia No. 25 Year 2011 on Implementation of Narcotics Addict Obligation.
} 
Institution (BAPAS) is a sub system of Sustainable Rehabilitation. The dominant aspects of the correctional guidance standards of Correctional Institution (BAPAS) clients include: procedural administration, facilities fulfillment, program planning, organizing post-rehabilitation guidance services, program implementation, supervising, monitoring and evaluating. ${ }^{8}$

2. Implementation of Post-Rehabilitation Guidance to Correctional Client in Class I Correctional Center of Semarang

The implementation of Post-Rehabilitation Guidance Services in correctional center according to Law No Law No. 12/1995 concerning Correctional Institution is set forth in Article 5 letter $\mathrm{d}$ which formulates about "Penal Correctional System is implemented based on the principle: (d) guidance".

Meanwhile, regarding tactical and technical guidance services for correctional clients according to Law No. 12 of 1995 on Correction of Article 44 formulates "The provisions concerning the client guidance program shall be further regulated under a Government Regulation"9. So in terms of implementation and governance of post-rehabilitation guidance is regulated in government regulations.

Government Regulation No. 31 of 1999 on the Implementation of Guidance and Counseling for Correctional Prisoners, Article 31 determines: ${ }^{10}$

1. Head of BAPAS shall perform client guidance;

2. In conducting the guidance as referred to in sub-article (1) the Head of BAPAS shall conduct an implementation plan, and control over the activities of the guidance program.

3. The guidance activities referred to in sub-article (2) shall be directed to the Client's ability to integrate healthily with the community.

Ministry of Justice and Human Rights (KEMENKUMHAM) is the institution

8 Interview with Mr. Imam Sarwoto, Bc.IP, S.Sos, the chief of Class I Correctional Center of Semarang Central Java, on 26 May 2017

9 Article 44 Law No. 12 Year1995 on Correctional Institution

10 Article 31 Government Regulatin No. 31 Year1999 on on the Implementation of Guidance and Guidance for Prisoners of Correctional Facilities. of command in charge of socialization in Indonesia. Through the Decree of the Director General of Correctional of the Ministry of Law and Human Rights of the Republic of Indonesia No: PAS-11.PR.01.02 Year 2016 on Standards Guidance Independence of Correctional Clients, correctional client governance is regulated in more detail.

Meanwhile, in Article 2 Paragraph (1) of the Decree of the Minister of Justice of the Republic of Indonesia No: M.01-PK.10 of 1998 regulates the Guidance of Personality and Guidance of Self-Reliance for Prison Clients.

The governance of correctional clients in Correctional Institution (BAPAS) generally contains guidance on clients who have a social / assimilation / Criminal (Pib) integration process. ${ }^{11}$ So the category of correctional clients served by their supervision by BAPAS includes:

1. The condemned conditional client

2. Client's parole

3. Clients Leave free leave

The guidance of correctional clients which is part of the penal system that animates the criminal justice system and contains aspects of law enforcement in order to prevent crime and guidance for law-breakers intended for the benefit of client's integration with the community, adheres to the basic principles of governance as follows: ${ }^{12}$

1. Administrative procedural aspect.

2. Aspect of fulfillment of facilities in the implementation of guidance.

3. Aspects of Planning

4. Organizing Aspects

5. Aspects of Implementation

6. Monitoring Aspect which consists of monitoring and evaluation of guidance implementation

From the exposure of the implementation of post-rehabilitation

\footnotetext{
11 Interview Bapak Imam Sarwoto, Bc.IP, S.Sos, the chief of Class I Correctional Center of Semarang Central Java, on 26 May 2017.

12 Direktorat Jenderal Pemasyarakatan, Op.Cit p 4.
} 
guidance program for penitentiary clients, the researcher can analyze as follows:

a. Post-rehabilitation holds the last vital role considering this stage is the end of continuous rehabilitation. If the implementation is not perfect because of the complexity of drug treatment from the investigation stage by the police / BNN to the judge's decision on the narcotics court, this is reasonable if there is miscoordination, law enforcement is not firm and coordination between agencies that handle it. As the findings of Krisnawati and Utami's research (2014) entitled Rehabilitation for Narcotics Addicts in the Stages of Investigation after the Enactment of the Joint Regulation of 7 (seven) State Institutions of the Republic of Indonesia ${ }^{13}$, which said that despite the mandate of narcotic law, compulsory narcotics addict undergoing rehabilitation, but the application is not yet complete so BNN initiated an agreement from 7 (seven) state institutions to prioritize rehabilitation for narcotics addicts.

b. As a law enforcement institution, Class I Correctional Center of Semarang has run the mandate as stated in Law no. 12 Year 1995 about correctional duties that perform the duties, the principal functions in the form of guidance for penal clients.

c. Implementation of post-rehabilitation guidance for the client of narcotic narcotics underlies its activities with the spirit of continuous rehabilitation that is the stages (reaching 3 stages) in guiding or training the independence of narcotics clients. This confirms that the treatment at the end of the guidance of narcotics is still a gradual treatment given the psychosocial, spiritual and vocational elements of multi-complex clients.

The implementation of post-rehabilitation guidance services for correctional clients with narcotics criminal acts contains dominant aspects

\footnotetext{
13 Krisnawati and Utami, 2014, Pelaksanaan Rehabilitasi Bagi Pecandu Narkotika Pada Tahap Penyidikan Pasca Berlakunya Peraturan Bersama 7 (tujuh) Lembaga Negara Republik Indonesia, UGM, Yogyakarta.
}

of procedural administration, client management through gradual and sustainable interventions, governance of mentoring activities that prioritize planning, organizing, implementation and monitoring through monitoring and evaluation.

The central role of cross-professions such as Community Counselors, Counselors, Psychologists, Doctors and other supporting professions such as Instructors of practical skills in the community, indicate the performance of post-rehabilitation service system for correctional clients in Class I Correctional Center of Semarang. The more cohesive they work, the better the performance of the post-rehabilitation service system.

\section{Constraints and Solutions for Improving the Implementation of Post-Rehabilitation Guidance for Correctional Clients in Class I Correctional Center of Semarang}

The post-rehabilitation guidance service system in Class I Correctional Center of Semarang, as a growing system, it has some limitations or system constraints. According to the researcher's study there are several factors that cause the performance of this system is less than optimal. The results of interviews and observations of researchers in Class I Semarang Central Java Prison, the authors classify the obstacles of implementation of post-rehabilitation guidance for clients correctional narcotics crime into 2 (two) factors, namely:

a. Internal Client Factor

b. External Client Factors

To examine it more deeply, the author discussed it in the sub following chapter.

\section{Implementation Constraints on Post- Rehabilitation Guidance}

The researcher has classified the constraints of the implementation of post-rehabilitation guidance into two factors, namely internal and external. Given the client is the subject of treatment and treatment is done in a sustainable then based on the author's research can be explained as follows: ${ }^{14}$

\footnotetext{
14 Interview with Mr. Imam Sarwoto, Bc.IP, S.Sos the chief of Class I Correctional Center of Semarang, Bapak Soni Yuniyanto, Counselor and instructors in Class I Correctional Center of Semarang, 26 May 2017
} 
a. Internal Client Factor

Client cannot attend according to schedule determined by Class I Correctional Center of Semarang. This is due to the client's awareness and client's economic needs. The element of the client's self-awareness is related to the understanding and the psychic perspective that feels that he/she has "recovered" from the narcotic dependency. The reason there are some of the clients who are already working to finance the family's living. So, the clinical and psychosocial outlook on post-rehabilitation guidance is a clash between the ideals (planned for the treatment intervention) and the actual occurrence of the client. The next factor of follow-up is the economic element of the family. The client's need to fulfill the family's livelihood takes precedence over the client rather than following the postrehabilitation guidance service. From the data collected, clients work in the private sector which cannot permit at any time.

\section{b. Client External Factors}

According to the information submitted by Chief of Administration representing the Chief of Correctional Center as the person in charge of post-rehabilitation activities of the client of narcotics criminal acts, the external elements cause the program constraints is the lack of transport costs that are not in accordance with the income from the work left behind. As government policy in the case of rehabilitation of addicts, drug abusers and/or victims of narcotics abuse is borne by the state. As stated in the List of Budget Implementation (DIPA), Class I Correctional Center of Semarang is transportation money for participants Rp 50.000, - (fifty thousand rupiah). This amount becomes a significant constraint if the client comes from out of Semarang City.

In addition to the issue of transportation, money is still in the field of budget, participants are not provided lunch when the activity lasted until even past lunch hour. The impact faced by the participants is lack of focus and lack of enthusiasm when approaching and entering the lunch hour.

\section{Solution Improvement Constraints Implementation Post-Rehabilitation Guidance \\ In accordance with the mapping constraints} that the researcher describes in the previous subsub chapter, then alternative remedial solutions include:

a. Aspects Inside the Correctional Clients Given that post-rehabilitation guidance is a downstream sustainable rehabilitation system, then the elements of the previous stages become strategic for optimized subsystem performance. For example, early diagnostic enforcement is really effective. So that the resources used during rehabilitation were highly focused, thus in terms of budgeting and effectiveness of drug clients running well.

In addition, the guidance phase is a continuation of the stages of mentoring in prisons, therefore it is needed the accuracy of prisoners' data of narcotic criminal behavior before changing their status of a penalty client. These data and information are related to the individual prisoner profile based on their recent update data. The characteristics of correctional clients when Litmas was run refer to the latest inmate data.

Optimizing the management of the client, as a "sick" person, it needs to be a platform for all parties involved in the ongoing rehabilitation program, ranging from investigators, prosecutors, judges, prison officers, paramedics and community counselors in Class I Correctional Center of Semarang.

b. Implementation of Budget Aspects

The budget aspect in the implementation of post-rehabilitation programs for correctional clients has been limited by DIPA. So the proposed nominal change component of the cost of organizing can only be through 
political channels and budget policy by the government.

But there is also a gap to get a postrehabilitation financing budget that does not violate the legal protection of its implementation is through the expansion and intensity of third-party networks. Such as private companies that care about drugs through programs in Corporate Social Responsibility companies.

\section{CONCLUSION}

The prevention system of narcotic drug reprisals for correctional clients is a set of integrated system components covering initial registration, rehabilitation, post rehabilitation and termination. In the management of addicts, the abuse and/or the victim of narcotic drug abuse is known as continuous rehabilitation. In this continuous process, there is a multidisciplinary profession both medical and legal, which mutually reinforces and fills the system. Therefore, suspected narcotic criminal acts capable of intervention therapy gradually and sustainably, through coaching in prisons and supervision in Class I Correctional Center of Semarang. Specifically on biopsychosocial, spiritual and vocational interventions, coaching are done in Class I Correctional Center of Semarang known as post-rehabilitation guidance services. Thus for penitentiary clients who recover from narcotic dependence can be productive again live in the community, without any demand against drugs.

Implementation of post-rehabilitation guidance in Class I Correctional Center of Semarang, prioritizing governance on procedural aspects of administration, fulfillment of facilities, planning, organizing, implementation, supervising and monitoring and evaluating. The conduct of this guidance activity is based on the control of layered systems both legally and medically. Inherent supervision takes place within the client's social integration process with the environment, in the form of evidence of family commitment/client guarantees in productive endeavors facilitated by Class I Correctional Center of Semarang.

Obstacles in the implementation of postrehabilitation guidance in Class I Correctional Center of Semarang is divided into 2 (two) sectors. There are internal and external factors of correctional clients. Factors from the internal client contribute to the problem or obstacle of the implementation of guidance is the presence of the client on a predetermined schedule. As brace indicator is the awareness of clients who are less to the appreciation of the program conducted by Class I Correctional Center of Semarang. Another sector from the client is family economic needs.

To improve the foresight of the medical profession and the law in viewing the problem of narcotic crime lies in the "immediacy" of this case. Addicts, abusers and/or victims narcotics abuse is urgent to be investigated, user urine has an expiration time of 2 times 24 hours. Therefore, the speed and accuracy of the initial diagnosis of the client determine the stage of clinical, psychological, and law enforcement interventions.

Accuracy of re-assessment on postrehabilitation program is more effective. For the reason that the client's individual profile, after changing the status of the prisoner, largely determines the suitability of the programs implemented on post-rehabilitation services. With the right effectiveness of re-assessment, saving the resources of organizing activities can be done.

Limitations of post-rehabilitation service budgeting can be pursued in a more creative way by cooperating with private parties directly related to drugs, such as pharmaceutical companies, hospitals and health insurance providers. This needs to be done because the cost of drug rehabilitation can be expensive if it is not supported by related sub-sectors. It is expensive because it touches the productivity of Indonesian human resources.
IMPLEMENTATION OF POST REHABILITATION GUIDANCE TO CLIENTS OF CORRECTIONAL INSTITUTION IN THE FRAMEWORK OF PREVENTION OF RELAPSING TO NARCOTICS CRIMINAL ACTS Djauhari, Aditya Sarjana Putra 


\section{BIBLIOGRAPHY}

Badan Narkotika Nasional Republik Indonesia, 2015, Petunjuk Teknis Layanan Pascarehabilitasi di Bapas, Jakarta;

Direktorat Jenderal Pemasyarakatan, 2016, Standar Bimbingan Klien Dewasa, Jakarta,

Krisnawati dan Utami, 2014, Pelaksanaan Rehabilitasi Bagi Pecandu Narkotika Pada Tahap Penyidikan Pasca Berlakunya Peraturan Bersama 7 (tujuh) Lembaga Negara Republik Indonesia, UGM, Yogyakarta;

Lexy J. Moleong, 2000. Metodologi Penelitian Hukum. Citra Aditya Bakti. Bandung;

Pusat Penelitian Data dan Informasi Badan Narkotika Nasional Republik Indonesia, 2015, Survei Prevalensi Penyalahgunaan Narkoba pada Kelompok Rumah Tangga di 20 Provinsi Tahun 2015. Jakarta Timur

Soerjono Soekanto, 1984, Pengantar Penelitian Hukum, Universitas Indonesia Pers, Jakarta. Law No 35 Year 2009 about Narkotika.

Peraturan Pemerintah No. 31 Tahun 1999 about Pelaksanaan Pembinaan dan Pembimbingan Bagi Warga Binaan Pemasyarakatan

https://www.bps.go.id/brs/view/id/1229. 